\title{
Anamirta cocculus Toxicity in Malnad Gidda Cattle: A Case Report
}

\author{
N. B. Shridhar* \\ Obscure Disease Research Center, Veterinary College Campus, \\ KVAFSU, Shivamogga-577204, Karnataka, India \\ *Corresponding author
}

\section{Keywords}

Anamirta cocculus,

Malnad Gidda

Cattle, Toxicity,

Clinical Signs,

Diazepam,

Xylazine, Dextrose,

Article Info

Accepted:

10 April 2020

Available Online:

10 May 2020

\section{A B S T R A C T}

In Tirthahalli of Shivamogga District of Karnataka State, 11 Malnada Gidda cattle of different age group succumbed to toxicity and exhibited the clinical signs of anorexia, shivering, nervousness, lethargy and wobbling gait. Ailing animals were treated symptomatically with diazepam, xylazine, fluids and B-complex vitamins with administration of activated charcoal. On obtaining the history and visit to the affected area, it was evident that the animals had consumed the fruits of the plant Anamirta cocculus. Blood analysis of the ailing animals revealed no change in the haematological and biochemical parameters except hyperglycaemia. Post mortem finding revealed extensive hemorrhage in the brain with no change in the other organs.

\section{Introduction}

Plant toxicity is a common cause of the morbidity and mortality of cattle in Western Ghats of Karnataka State. Malnad Gidda cattle are habitat of Western Districts of Karnataka State and let out for grazing in forest and do have more access to toxicity of plants. It is said that these cattle do can differentiate the poisonous from edible plant which seems to be false. Because of the edible nature of the plants like Embelia tserium Cottom and Mimosa invisa cattle and buffaloes do consume them and succumb to toxicity.

They also succumb to toxicity by accidental consumption of leaves Ficus tsjahela and Hevea brasiliensis cut by farmers (Lohith et al., 2014; Shridhar et al., 2014; Shridhar, 2017). Anamirta cocculus is a climbing plant from India and other parts of Southeast Asia. 
It is is known for its large stems of white wood and scented flowers (Figure 1 and 2). It produces small fruits with sweet pulp (Verpoorte et al., 1981). During the fruiting season, Malnad Gidda cattle do consume the fruits fallen on the ground because of the sweet nature of the pulp of the fruits and also rarely consume the leaf of the plant when there is scarcity of fodder. The seed of fruits of the plant do contain a potent toxin picrotoxin, which is a very strong neurotoxin in all vertebrates affecting CNS. Fresh or dry semi-ripe fruits with or without the fruit pulp is ground and used as fish stupefying agent. In India and South-East Asia the fruit of Anamirta cocculus is used mainly as a fish poison (Duman et al., 2001; Jijith et al., 2016).

The data on toxicity features of Anamirta cocculus in cattle is scanty. Hence, the present study was aimed to evaluate the toxic feature of the plant and to study the changes in hematological and serum biochemical changes and also to evaluate the effectiveness of treatment.

\section{Case study}

In Chikkahodala village, Tirthahalli Taluk, Shivamogga District of Karnataka, 12 Malnad Gidda ( 8 Female and 4 males) cattle with age ranging from from 5-11 years reported to be exhibiting the clinical signs of anorexia, shivering, nervousness, lethargy and wobbling gait. Out of 12 animals, 7 died ( 5 female and 2 males) succumbed to death after exhibiting the said clinical signs within a span of $24 \mathrm{~h}$. The onset of the toxicity was initiated with abnormal gait causing in coordination during getting up and walking. Excitement and salivation were the early clinical signs later with severe excitation. There was clonic convulsions with paddling of the limbs. There was blurred vision in affected animals confirmed by diminished palpebral reflex
(Figure 3 and 4). There was projectile regurgitation. There was anxiety in mild to moderate convulsions were observed in few animals. The site was visited and it was observed that all the cattle had consumed the fruits of the plant Anamirta cocculus which was present in the grazing area and it was the fruiting season.

The temperature, respiratory rate and heart rate were recorded timely. Blood samples from the affected Malnad Gidda cattle were obtained at the intervals of 24, 48, 72 and 96 $\mathrm{h}$ following the onset of the signs of toxicity. To serve as the control, the blood was also drawn from the other healthy Malnad Gidda cattle without toxicity.

The Malnad Gidda cattle exhibiting the clinical signs of the toxicity were treated with diazepam @ $0.5 \mathrm{mg} / \mathrm{kg}$ slow IV, xylazine 0.1$0.2 \mathrm{mg} / \mathrm{kg} \mathrm{IM}$, B-complex vitamins, IM, intravenous administration of $5-10 \mathrm{ml} / \mathrm{kg}$ of $10 \%$ dextrose solution, activated charcoal @ $2 \mathrm{~g} / \mathrm{kg}$ orally twice at 10 to $12 \mathrm{~h}$ interval for three consecutive days.

Alanine aminotransferase (ALT), aspartate aminotransferase (AST), blood urea nitrogen (BUN), serum creatinine (CRT), calcium, magnesium, phosphorus and glucose were estimated in serum of the affected as well as the normal control Malnad Gidda animals.

Postmortem of animals succumbed to death was conducted and the gross lesions were noted. Representative brain, heart, spleen, intestine, kidney, liver, rumen, and abomasum tissue samples were collected for histopathology at $10 \%$ neutral buffered formalin (NBF).

\section{Results and Discussion}

Examination of the affected animals revealed increased body temperature $\left(105.7^{\circ} \mathrm{F}\right)$, 
tachycardia (115/min) and tachypnoea (30/min). This might be due to the convulsive episodes and excitation followed by depression similar to that is observed in many neurotoxicities and plant toxicities like Ficus tsjahela (Shridhar, 2017).

The important clinical sign of Anamirta cocculus toxicity in Malnad Gidda cattle included clinical signs of, shivering, anorexia, nervousness, lethargy and wobbling gait. Most of the animals (7/11) succumbed to death indicated the severity of the toxicity. Few of the clinical signs of the toxicity resembled to neurotoxicity in Ficus tsjahela toxicity as reported earlier (Shridhar et al., 2014; Shridhar, 2017) .

Picrotoxin is the active principle of the fruit pulp of the plant Anamirta cocculus. Picrotoxin is a convulsant and in larger doses induces clonic convulsions and cardiac dysrhythmias. Picrotoxin induces the convulsions by blocking $\alpha 2$ homomeric glycine receptors (Newland and Cull-Candy, 1992, Wang et al., 2007). Death occurs rapidly due to respiration failure, or slowly from gastrointestinal symptoms, particularly the medulla oblongata and respiratory centre.

The acute death in the present study in affected cattle might be due to respiratory failure and rather than gastrointestinal signs as they were less evident. The clinical signs exhibited by the Malnad Gidda cattle do resemble the toxicity features of many neurotoxic plants especially Ficus tsjahela toxicity in cattle and buffaloes (Shridhar et al., 2014; Shridhar, 2017).

The surviving Malnad Gidda cattle exhibiting the clinical signs of toxicity were administered with $0.5 \mathrm{mg} / \mathrm{kg}$ diazepam slow IV, $5-10 \mathrm{ml} / \mathrm{kg}$ dextrose solution IV along with B-complex vitamins for 3 days in an interval of $24 \mathrm{~h}$. Improvement in the condition was observed by getting up and consumption of feed or water followed by voiding the dung or urine. On day 4 of the treatment most of the animals got recovered. There was no re occurrence of the toxicity signs in any of the treated Malnad Gidda animals. This might indicate that the toxin might have excreted from the body (Shridhar, 2017).

Administration of diazepam @ $0.25-0.5$ $\mathrm{mg} / \mathrm{kg}$ slow IV in an interval of 10-12 $\mathrm{h}$ and xylazine @ 0.1-0.2 mg/kg IM made satisfactory recovery of the treated animals subsiding the clinical signs and restoring their normal physical and physiological activity within $72 \mathrm{~h}$.

Diazepam is a benzodiazepine that exerts anticonvulsant, sedative, anxiolytic, musclerelaxant, and amnestic effects. These effects are brought by mimicking gamma aminobutyric acid (GABA) receptor which are inhibitory in nature in CNS. It is also a drug for short term treatment of epilepsy. Being a good sedative, it has got the antianxiety property.

The recovery of the animals might be attributed to this. Hence, the clinical signs might have subsided (Mandrioli et al., 2008; Riss et al., 2008). Picrotoxin initiates its action through GABA receptor. The satisfactory clinical recovery of the Malnad Gidda animals in Anamirta cocculus toxicity indicated the dose and interval selected might be appropriate (Booth and McDonald, 1998). Pankaj Kumar Patel et al., (2018) also managed the calf with ivermectin toxicity exhibiting the neurological signs with administration of diazepam.

One of the the preferred sedative in cattle is xylazine which is administered IM @ 0.1-0.2 $\mathrm{mg} / \mathrm{kg}$ for long time of action. Xylazine is a anticonvulsant sedative and one of the most commonly used $\alpha 2$ adrenergic receptor 
agonist in cattle. In the present study, it was used @ 0.1-0.2 mg /kg IM.In this dose, it reversed the toxicity clinical signs (Zuhair et al., 2010; Lakech and Kindalem, 2019; Michael et al., 2015).

In the present study, activated charcoal was administered at the dose of $2 \mathrm{~g} / \mathrm{kg}$ orally as a 1:8 slurry which might have adsorbed the toxins from the gut. The activated charcoal is a black powder available as a laboratory grade chemical which produces a fine suspension when mixed with water. In much toxicity in cattle, activated charcoal is used for the treatment effectively.

Activated charcoal is administered in toxicities in early stage before absorption of the toxin/s into circulation or during the onset of clinical signs of the toxicity to inhibit the further absorption of the toxicants in the gut.

Many plant toxicities were treated effectively by administration of activated charcoal in similar dose with examples of Lantana toxicity (Michael and Coralie Stewart, 1984, Gupta et al., 2019) and Yellow tulp (Moraea pallid ) toxicity (Snyman et al., 2009).

Vital dietary supplements include B-complex vitamins in which thiamine are an important vitamin which is needed for metabolism of carbohydrates. Other important components of B-complex vitamins include riboflavin and cobalamin. In carbohydrate metabolism thiamine is a cofactor and produces energy in carbohydrate metabolism for formation of thiamine pyrophosphate.

Opisthotonus, circling movements, listlessness, muscle tremors in ruminants will be exhibited by ruminants in impairment in its synthesis or deficiency affects that the carbohydrate metabolism. Due to deficiency of thiamine, polioencephalomalacia (PEM) a non-infectious nutritional deficiency disease in which there will be the neurological signs. The clinical signs in present study do have similarity to PEM. In the present study, Bcomplex vitamins containing thiamine hydrochloride with administration of dextrose might augmented the recovery of the toxicity affected Malnad Gidda animals (Christiane, 2017, Tolga et al., 2010).

In estimated biochemical parameters, an increase $(\mathrm{P}<0.05)$ in blood glucose of the affected animals during the course of toxicity which returned to normal at $96 \mathrm{~h}$ with no change in ALT, AST, BUN,CRT, calcium, magnesium and phosphorus was noticed (Table 1). There was no change in the hematological parameters in the present study (Table 2).

In the present study there was an increase in the blood glucose concentration which returned to normal after the animal's recovery. This might be attributed to clonic convulsions leading to increased skeletal muscles activity might be the cause of hyperglycemia.

Increased skeletal muscle activity requires more glucose. Acute hyperglycemia during clonic convulsions suggested reflux increase in muscle activity and increase in blood glucose concentration (Ratnasooriya et al., 1992, Geetha et al., 1994)

There was no change in the hematological parameters during the course of toxicity indicating that the toxicity had not affected system and this is accordance with the finding of few workers who also noted that no change in such parameters (Mathew et al., 2014).

Extensive hemorrhages in the brain of the affected Malnad Gidda animals was observed during the post mortem. There were degenerative changes in the neurons and glial cells (Figure 5 and 6). 
Table.1 Biochemical profile of Malnad Gidda cattle affected with Anamirta cocculus toxicity (Mean \pm SEM)

\begin{tabular}{|c|c|c|c|c|c|c|}
\hline \multirow[t]{2}{*}{ Parameter } & \multirow{2}{*}{$\begin{array}{c}\text { Apparently } \\
\text { healthy Malnad } \\
\text { Gidda cattle } \\
(n=6)\end{array}$} & \multicolumn{5}{|c|}{ Malnad Gidda cattle affected with Anamirta cocculus toxicity $(\mathrm{n}=5)$} \\
\hline & & 0 hour & 24 hours $^{\#}$ & 48 hours $^{\#}$ & 72 hours & 96 hours \\
\hline $\begin{array}{l}\text { Alanine amino } \\
\text { Transferase } \\
\text { (ALT in U/L) }\end{array}$ & $31.5 \pm 3.19$ & $28.17 \pm 1.99$ & $29.68 \pm 2.58$ & $26.30 \pm 2.83$ & $26.53 \pm 2.74$ & $28.82 \pm 2.66$ \\
\hline $\begin{array}{l}\text { Aspartate amino } \\
\text { Transferase } \\
\text { (AST in U/L) }\end{array}$ & $59.25 \pm 2.58$ & $56.87 \pm 2.62$ & $59.97 \pm 2.26$ & $59.39 \pm 2.68$ & $56.83 \pm 2.63$ & $57.36 \pm 1.65$ \\
\hline $\begin{array}{l}\text { Blood Urea } \\
\text { Nitrogen } \\
\text { (BUN in U/L) }\end{array}$ & $19.66 \pm 1.62$ & $21.38 \pm 2.64$ & $23.16 \pm 1.25$ & $20.73 \pm 1.45$ & $19.25 \pm 2.88$ & $21.25 \pm 1.98$ \\
\hline $\begin{array}{l}\text { Creatinine } \\
(\mathrm{mg} / \mathrm{dl})\end{array}$ & $1.13 \pm 0.23$ & $1.29 \pm 0.37$ & $1.72 \pm 0.23$ & $1.98 \pm 0.95$ & $1.89 \pm 0.63$ & $1.63 \pm 0.26$ \\
\hline Calcium (mg/dl) & $11.39 \pm 1.39$ & $11.38 \pm 1.69$ & $11.98 \pm 1.36$ & $11.59 \pm 1.96$ & $12.98 \pm 1.99$ & $11.99 \pm 1.69$ \\
\hline $\begin{array}{l}\text { Magnesium } \\
\text { (mg/dl) }\end{array}$ & $2.79 \pm 0.56$ & $2.69 \pm 0.76$ & $2.36 \pm 0.18$ & $2.99 \pm 0.91$ & $2.75 \pm 0.63$ & $2.89 \pm 0.66$ \\
\hline $\begin{array}{l}\text { Phosphorus } \\
\text { (mg/dl) }\end{array}$ & $4.98 \pm 0.99$ & $4.79 \pm 0.65$ & $4.69 \pm 0.39$ & $4.96 \pm 0.23$ & $4.87 \pm 0.28$ & $4.72 \pm 0.29$ \\
\hline Glucose (mg/dl) & $87.94 \pm 3.92$ & $84.64 \pm 2.98$ & $271.4 \pm 22.3^{*}$ & $189 \pm 11.36^{*}$ & $89 \pm 2.77$ & $84.75 \pm 2.25$ \\
\hline
\end{tabular}

*P $<0.05$; ${ }^{*}$ Treatment was given with diazepam $0.5 \mathrm{mg} / \mathrm{kg}$, xylazine $0.1-0.2 \mathrm{mg} / \mathrm{kg}$ im ,

B-Complex $10 \mathrm{ml} \mathrm{i/m}$ and 5-10 $\mathrm{ml}$ of $10 \%$ dextrose solution $\mathrm{i} / \mathrm{v}$

Table.2 Haematological profile in Malnad Gidda cattle affected with Anamirta coculus toxicity (Mean \pm SEM)

\begin{tabular}{|c|c|c|c|}
\hline Group & $\begin{array}{l}\text { Healthy Malnad } \\
\text { Gidda cattle } \\
(n=6)\end{array}$ & $\begin{array}{c}\text { Malnad Gidda cattle with } \\
\text { toxicity } \\
(n=5)\end{array}$ & Reference values \\
\hline RBCs $\left(10^{6} / \mu 1\right)$ & $7.89 \pm 1.97$ & $7.98 \pm 0.64$ & $5.0-10.0$ \\
\hline $\mathrm{Hb}(\mathrm{g} / \mathrm{dl})$ & $12.56 \pm 0.96$ & $12.97 \pm 0.63$ & $8-15$ \\
\hline $\operatorname{PCV}(\%)$ & $35.18 \pm 2.63$ & $34.29 \pm 0.96$ & $24-46$ \\
\hline $\operatorname{MCV}(\mathrm{fl})$ & $48.19 \pm 5.45$ & $45.36 \pm 5.81$ & $40-60$ \\
\hline $\mathrm{MCH}(\mathrm{pg})$ & $14.19 \pm 2.4$ & $14.40 \pm 3.28$ & $11-17$ \\
\hline WBCs $\left(10^{3} / \mu 1\right)$ & $11.58 \pm 1.56$ & $12.63 \pm 4.98$ & $4.0-12.0$ \\
\hline Platelets $\left(10^{3} / \mu 1\right)$ & $296.54 \pm 68.97$ & $264.29 \pm 49.87$ & $100-800$ \\
\hline Lymphocytes (\%) & $61.98 \pm 4.56$ & $56.48 \pm 4.63$ & $62-63$ \\
\hline Neutrophils (\%) & $31.83 \pm 5.46$ & $40.78 \pm 1.89$ & $15-33$ \\
\hline Eosinophils (\%) & $12.34 \pm 0.68$ & $11.87 \pm 0.98$ & $0-20$ \\
\hline Monocytes (\%) & $6.15 \pm 0.78$ & $5.79 \pm 2.21$ & $0-8$ \\
\hline
\end{tabular}

The values are expressed as Mean \pm SEM.

RBCs, Red blood cells; Hb, Hemoglobin; PCV, Packed cell volume; MCV, Mean corpuscles volume; MCH, Mean corpuscles hemoglobin; WBCs, White blood cells. 


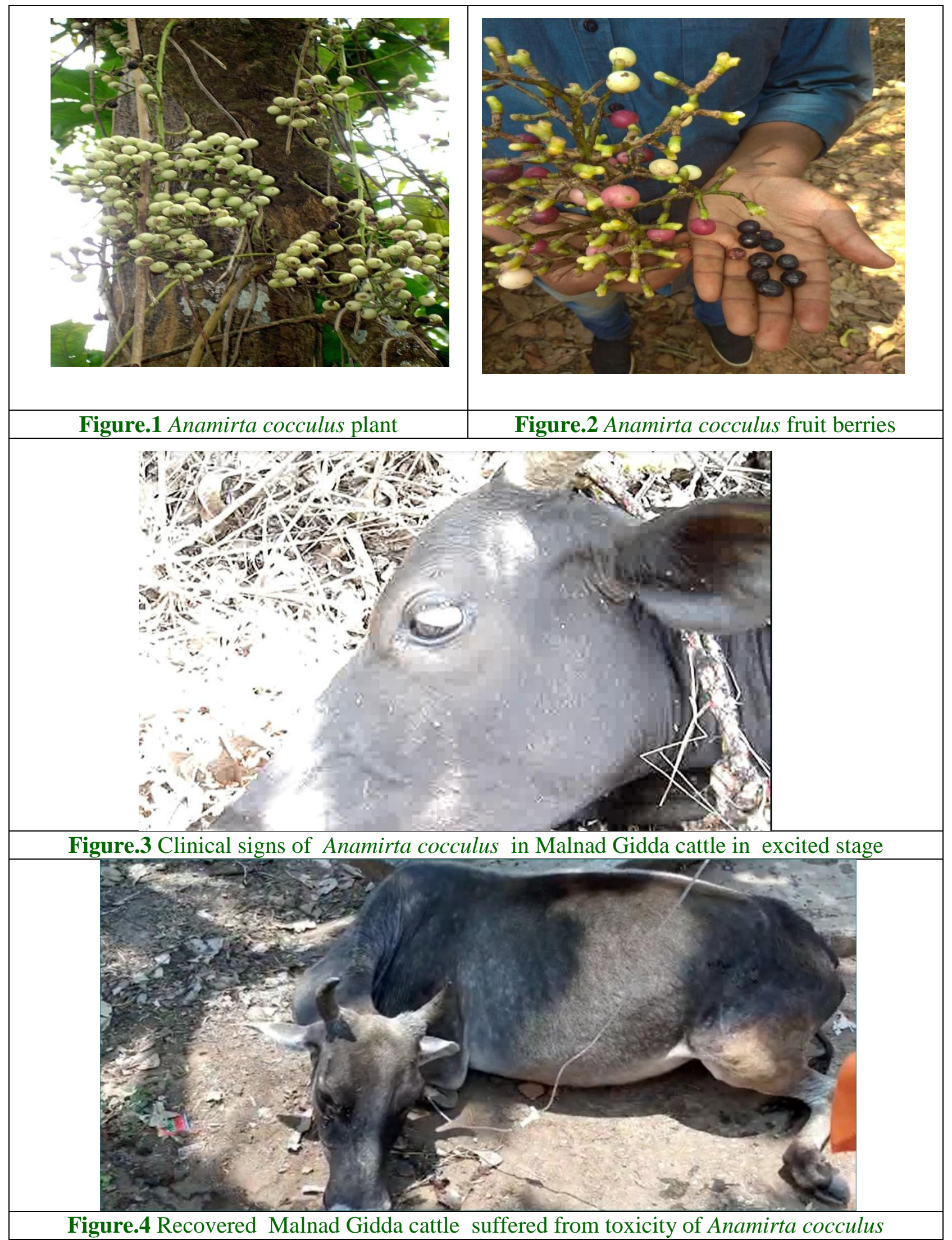




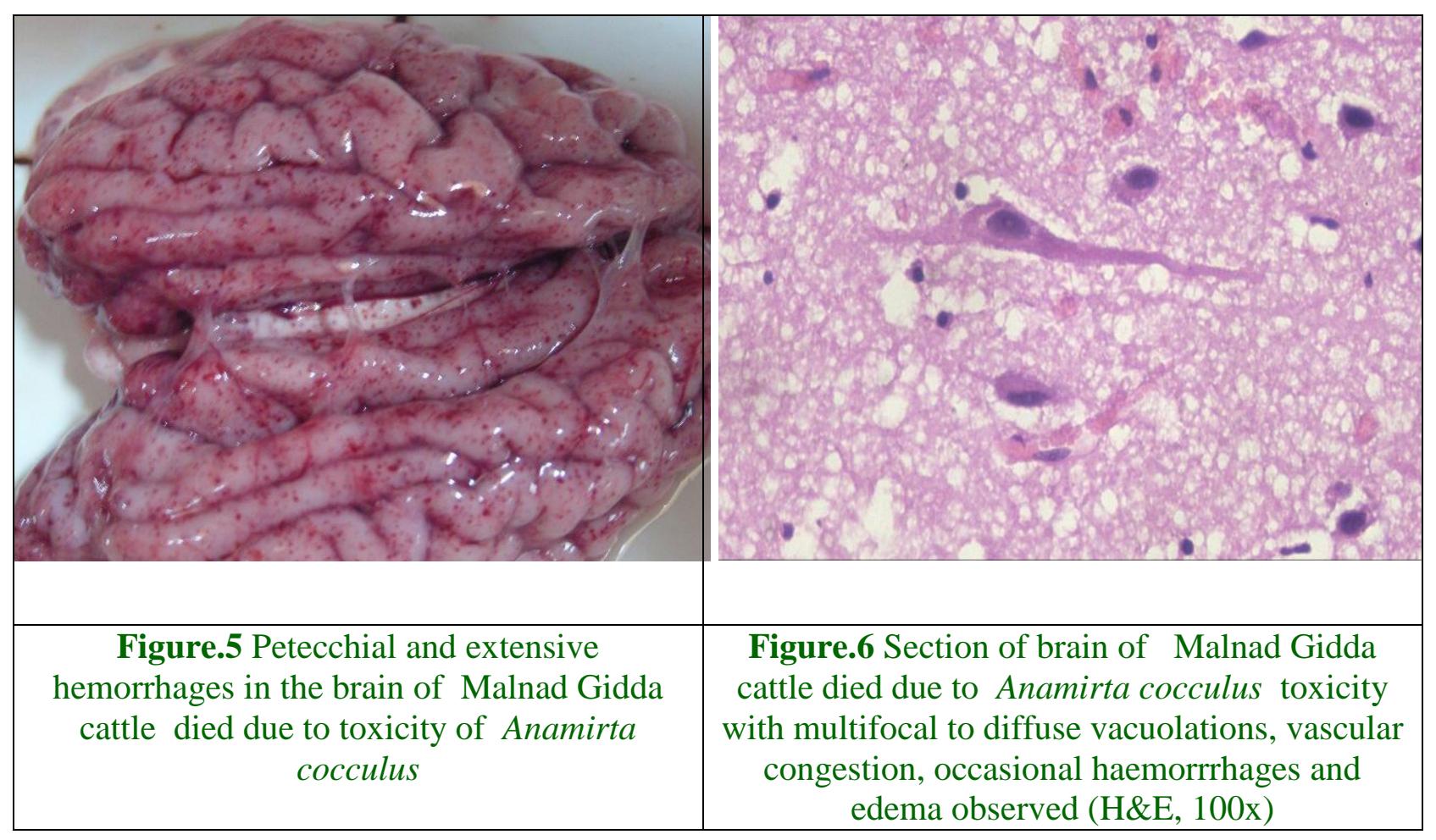

The brain histological findings were degenerative changes in the neurons and glial cells, vacuolation and myelin degeneration with structural alterations in axosomatic and axodendritic synapses. Similar type of the brain change was also observed in Ficus ingens toxicity in cattle indicating the neurotoxic nature of the picrotoxin ( Myburgh et al., 1994).

\section{Acknowledgements:}

The financial assistance by Government of Karnataka for establishment of Obscure Disease Research Center in the campus of Veterinary College, Shivamogga for the study of diseases of unknown etiology in cattle and buffaloes is sincerely acknowledged.

\section{References}

Booth, N.H. and McDonald, L.E. 1998. Psychotropic agents. In: Veterinary Pharmacology and Therapeutics, $6^{\text {th }}$ ed. Panima Publishing Corporation, New Delhi, 363-395.

Christiane L.G. 2017. New approaches, development, and improvement of methodologies for the assessment of Bvitamin requirements in dairy cows. Brazilian J Animal Sci., 46(7):614-620

Duman, E. , Dorucu M. and D. Sen , 2001. Toxic effects of fish-seed (Anamirta cocculus) on Carp (Cyprinus carpio). J Biol Sci., 1: 1093-1094.

Geetha, B.S., Mathew, B.C. and Augusti, K.T. 1994. Hypoglycemic effects of leucodelphinidin derivative isolated from Ficus bengalensis (Linn). Indian J. Physiol. Pharmacol., 38: 220222.

Gupta, R.K., Niyogi, D., Nayan, R., Singh, S.V., Mishra, A. and Varun, V.K. 2019. Clinicopathological study of Lantana camara toxicity in a sheep farm J. Pharmacogn. Phytochem., :8(4): 2219-2221

Jijith, U. SSudhakaran Nair, . C. R. , Ajithkumar, K. C. Pramod, K. 2016. Phytochemistry and Pharmacology of Anamirta cocculus Willd. Res. J. Pharmacogn. Phytochem, 8( 2):90-92

Lakech, E. and Kindalem, B. 2019. Evaluation of diazepam-xylazine-ketamine anaesthesia on 
physiological, haematological and serum biochemistry value of sheep (Study in Gondar Town). Int. J. Agri.Agribus., 2 (2):60 - 71

Lohith, T.S, Venkatesha M.D, Mallinath K.C, Sobharani, M. Shankar B.P. 2014. Hevea brasiliensis poisoning in Malnad Gidda cattle, Karnataka, India. International Research Journal of Pharmacy, 5(7): 578579.

Mandrioli, R., Mercolini, L. and Raggi, M.A. 2008. Benzodiazepine metabolism: An analytical perspective. Curr. Drug. Metab., 9:827-844

Mathew, L., Divakaran Nair, N., Vijayan, N. and Mercey, K. A. 2014. Hemato-biochemical and oxidative effect of fresh juice and ethanolic extract of Ficus tsiela Roxb in rats. Vet. World, 7(10): 890-894.

Michael, A. Pass and Coralie Stewart, 1984. Administration of activated charcoal for the treatment of Lantana poisoning of sheep and cattle. J.Applied Toxicol., 4(5):269-271.

Michael, S., Kent., J. and Sulli Popilsk, 2015. Preanesthesia, anesthesia, analgesia and euthanasia. In. Laboratory Animal Medicine. $3^{\text {rd }}$ Edn. American College of Laboratory Animal Medicine, Academic Press, Cambridge, US. 1135-1200

Myburgh, J.G., Fourie, N. Van der Lugt, J.J., Kellerman ,T.S., Cornelius S,T., Ward, C. A. 1994. A nervous disorder in cattle, caused by the plants Ficus ingens var. ingens and Ficus cordata subsp. salicifolia. Onderstepoort J. Vet. Res., 61(2):171-176.

Newland, C.F. and Cull-Candy, S.G. 1992.On the mechanism of action of picrotoxin on GABA receptor channels in dissociated sympathetic neurons of the rat. J.Physiol., 447:191-213

Pankaj Kumar Patel, Sawita Kumari Patel, Sonam Bhatt, Desh Deepak, Arun Prabhakar, Brijesh Patel, Chandrama Rabha and Dixit, S.K. 2018. Therapeutic management of ivermectin toxicity in a calf: A case report.
Int.J.Curr.Microbiol.App.Sci., 7(04): 19641969.

Ratnasooriya, W.D., Premakumar, G.A.S. and Tillekeratne, L.M.V. 1992. Exploratory behavior of male rats treated with a crude extract of Ficus tsiela leaves. Med. Sci. Res., 20: 233-234.

Riss, J., Cloyd, J., Gates, J. and Collins, S. 2008. Benzodiazepines in epilepsy: Pharmacology and pharmacokinetics. Acta Neurologica Scandinavica, 118 (2):69-86.

Shridhar, N. B., Krishna, N. S. and Santhosh Kumar, C. N. 2014. Toxicity of Ficus tsjahela leaves in cattle and its clinical management. Indian Vet.J. 91(7): 49-50.

Shridhar, N.B. 2017. Therapeutic management of toxicity of Ficus tsjahela leaves in cattle. Toxicol. Int., 24 (3): 313-318.

Snyman, L. D., Schultz, R. A., Botha, C. J., Labuschagne, L., Joubert, J. P. J. 2009. Evaluation of activated charcoal as treatment for Yellow tulp poisoning in cattle. J. South Afr. Vet. Assoc., 80(4): 274275.

Tolga, K., Murat, D. and Omer, K. 2010. Thiamine status of feedlot cattle fed a highconcentrate diet. Can. Vet. J., 51(11): 1251-1253.

Verpoorte, R. , Siwon, J., Tieken, M. E. M. and Baerheim Svendsen, A. 1981. Studies on Indonesian medicinal plants. The alkaloids of Anamirta cocculus. J. Nat. Prod., 44 (2): 221-224.

Wang, D.S., Buckinx, R., Lecorronc, H., Mangin, J.M., Rigo, J.M. and Legendre, P. 2007. Mechanisms for picrotoxinin and picrotin blocks of alpha 2 homomeric glycine receptors. J. Biol. Chem. 282(22):1601616035.

Zuhair, B.I., Khaleel, J. and Ahmad, A.M. 2010. Effects of xylazine-ketamine-diazepam anesthesia on blood cell counts and plasma biochemical values in sheep and goats. Comp. Clin. Pathol., 19:571-574.

\section{How to cite this article:}

Shridhar. N. B. 2020. Anamirta Cocculus Toxicity in Malnad Gidda Cattle: A Case Report. Int.J.Curr.Microbiol.App.Sci. 9(05): 1090-1097. doi: https://doi.org/10.20546/ijcmas.2020.905.120 